\title{
Article \\ Influence of Terbium Ions and Their Concentration on the Photoluminescence Properties of Hydroxyapatite for Biomedical Applications
}

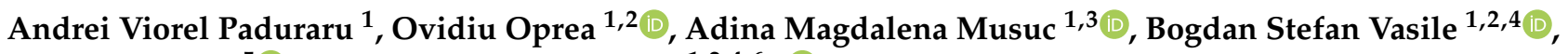 \\ Florin Iordache $5($ ib and Ecaterina Andronescu $1,2,4,6, *(1)$
}

1 Department of Science and Engineering of Oxide Materials and Nanomaterials, Faculty of Applied Chemistry and Materials Science University Politehnica of Bucharest, 060042 Bucharest, Romania; andrei93.paduraru@yahoo.com (A.V.P.); ovidiu73@yahoo.com (O.O.); amusuc@icf.ro (A.M.M.); bogdan.vasile@upb.ro (B.S.V.)

2 National Centre for Micro and Nanomaterials, University Politehnica of Bucharest, 060042 Bucharest, Romania

3 "Ilie Murgulescu" Institute of Physical Chemistry, Romanian Academy, 060021 Bucharest, Romania

4 National Research Center for Food Safety, University Politehnica of Bucharest, 060042 Bucharest, Romania

5 Department of Biochemistry, Faculty of Veterinary Medicine, University of Agronomic Science and Veterinary Medicine, 011464 Bucharest, Romania; floriniordache84@yahoo.com

6 Academy of Romanian Scientists, 50085 Bucharest, Romania

* Correspondence: ecaterina.andronescu@upb.ro

check for updates

Citation: Paduraru, A.V.; Oprea, O.; Musuc, A.M.; Vasile, B.S.; Iordache, F.; Andronescu, E. Influence of Terbium Ions and Their Concentration on the Photoluminescence Properties of Hydroxyapatite for Biomedical Applications. Nanomaterials 2021, 11, 2442. https://doi.org/10.3390/ nano11092442

Academic Editor: Jean-Marie Nedelec

Received: 19 August 2021

Accepted: 16 September 2021

Published: 19 September 2021

Publisher's Note: MDPI stays neutral with regard to jurisdictional claims in published maps and institutional affiliations.

Copyright: (c) 2021 by the authors. Licensee MDPI, Basel, Switzerland. This article is an open access article distributed under the terms and conditions of the Creative Commons Attribution (CC BY) license (https:/ / creativecommons.org/licenses/by/ $4.0 /)$.

\begin{abstract}
A new generation of biomaterials with terbium-doped hydroxyapatite was obtained using a coprecipitation method. The synthesis of new materials with luminescent properties represents a challenging but important contribution due to their potential applications in biomedical science. The main objective of this study was to revel the influence of terbium ions on the design and structure of hydroxyapatite. Different concentrations of terbium, described by the chemical formula $\mathrm{Ca}_{10-\mathrm{x}} \mathrm{Tb}_{\mathrm{x}}\left(\mathrm{PO}_{4}\right)_{6}(\mathrm{OH})_{2}$, where $\mathrm{x}$ is in the range of 0 to 1 , were considered. The consequence of ion concentration on hydroxyapatite morphology was also investigated. The morphology and structure, as well as the optical properties, of the obtained nanomaterials were characterized using X-ray powder diffraction analysis (XRD), Fourier Transform Infrared spectrometry (FTIR), SEM and TEM microscopy, UV-Vis and photoluminescence spectroscopies. The measurements revealed that terbium ions were integrated into the structure of hydroxyapatite within certain compositional limits. The biocompatibility and cytotoxicity of the obtained powders evaluated using MTT assay, oxidative stress assessment and fluorescent microscopy revealed the ability of the synthesized nanomaterials to be used for biological system imaging.
\end{abstract}

Keywords: terbium; rare earth ions; doped hydroxyapatite; coprecipitation method; photoluminescence; biological system imaging

\section{Introduction}

Photoluminescence is a significant and valuable instrument for the in situ study of tissue engineering and restoration, with fluorescent molecules having been used in clinical trials for a long time. In the last decade, many researchers have been focused on developing new biological luminescent compounds with special properties, e.g., high quantum yield and long fluorescence lifetime, for use in the medical field [1,2]. In this context, many bioceramics have been selected and used for reconstruction and/or to repair different types of tissue, applied as a coating, as cement, or as nanoparticles [3].

Hydroxyapatite $\left(\mathrm{HAp}, \mathrm{Ca}_{10}\left(\mathrm{PO}_{4}\right)_{6}(\mathrm{OH})_{2}\right)$, the essential mineral constituent of hard biological tissues such as teeth and bones [4], is used as a synthetic cement for bone and dental reconstruction due to its osteogenic, osteoconductive and osteoinductive properties $[5,6]$. 
Numerous research studies have suggested that nanoparticles of calcium phosphate can be used as fluorescent samples after doping with lanthanide by substitution of the $\mathrm{Ca}^{2+}$ ions, a method that also enhances the biological properties of HAp [7-11]. The substitution of $\mathrm{Ca}^{2+}$ ions can be made using various doping agents: carbon compounds [12-14], fluorine, chlorides and silicate [12] or cations-monovalent $\left(\mathrm{K}^{+}, \mathrm{Ag}^{+}, \mathrm{Na}^{+}\right)$[15-17], divalent $\left(\mathrm{Zn}^{2+}\right.$, $\left.\mathrm{Sr}^{2+}, \mathrm{Mg}^{2+}, \mathrm{Cd}^{2+}, \mathrm{Cu}^{2+}\right)[18-20]$ and trivalent $\left(\mathrm{Fe}^{3+}, \mathrm{Al}^{3+}\right.$, rare earths ions) [21,22]. In addition to medical uses, cation-substituted hydroxyapatite can also be used in multiple applications: sensors, catalysts, water decontamination, optoelectronics or radionuclides, and heavy metal remediation [23].

Luminescent rare earths have a surprising spectral nature, which allows them to be successfully used as a non-isotopic substitute for organic fluorophore compounds. Aside from in vivo detection of cell function applications, this group of elements is widely used for the luminescent marking of molecules to elucidate the structure and function of proteins and enzymes [24]. The photoluminescent properties of rare earth ions are mostly due to the narrow and strong electronic interconfigurational $f-f$ emission transitions [25], a large effective Stokes shifts, and high quantum yields [26].

Terbium ( $\mathrm{Tb}$, atomic number: 65$)$ is an important element in the rare earth group due to its interesting electronic, magnetic and optical properties, being also suitable for applications in the glass industry [27], polymers, biochemical sensors [28], and solar cells [29]. Due to its extensive development and use, terbium is inevitably present in organisms, the environment, and food chains.

Various researchers have shown that a smaller amount of doped $\mathrm{Tb}^{3+}$ ions can significantly increase its luminescence properties, while maintaining the main physicochemical properties and biological activities of the material [7]. Other researchers have evaluated the potential applications of $\mathrm{HAp} / \mathrm{Tb}^{3+}$ in the biomedical area and their results have shown an in vitro cytocompatibility with MC3T3-E1 and A549 cells. This fluorescence property of terbium-doped HAP nanomaterials makes them suitable to be incorporated into living cells $[30,31]$.

\section{Experimental Section}

\subsection{Materials}

All used reagents were of analytical grade and were used without further purification. Reagent-grade calcium nitrate tetrahydrate $\left(\mathrm{Ca}\left(\mathrm{NO}_{3}\right)_{2} \cdot 4 \mathrm{H}_{2} \mathrm{O}, 99.9 \%\right.$, Sigma Aldrich, St. Louis, MO, USA), terbium-(III) nitrate pentahydrate $\left(\mathrm{Tb}\left(\mathrm{NO}_{3}\right)_{3} \cdot 5 \mathrm{H}_{2} \mathrm{O}, 99.9 \%\right.$, Alfa Aesar, Haverhill, MA, USA), ammonium phosphate dibasic $\left(\left(\mathrm{NH}_{4}\right)_{2} \mathrm{HPO}_{4}, 99.0 \%\right.$, Alfa Aesar, Haverhill, MA, USA), and ammonia solution $\left(\mathrm{NH}_{4} \mathrm{OH}, 25 \%\right.$ solution) were used for the synthesis. The compounds were dissolved in deionized water.

\subsection{Synthesis Procedure}

Samples Notation: HAp represents the undoped hydroxyapatite; $\mathrm{Ca}_{10-\mathrm{x}} \mathrm{Tb}_{\mathrm{x}}\left(\mathrm{PO}_{4}\right)_{6}(\mathrm{OH})_{2}$ represents the hydroxyapatite doped with different concentration of terbium ions, where $\mathrm{x}=0$, $0.05,0.1,0.25,0.5$ and 1 .

The terbium-doped hydroxyapatite $\left(\mathrm{Ca}_{10-\mathrm{x}} \mathrm{Tb}_{\mathrm{x}}\left(\mathrm{PO}_{4}\right)_{6}(\mathrm{OH})_{2}\right)$ nanomaterials were synthesized using a coprecipitation method. The samples were obtained using the following synthesis procedure: initially, a solution was obtained by dissolving an appropriate amount of $\mathrm{Ca}\left(\mathrm{NO}_{3}\right)_{2} \cdot 4 \mathrm{H}_{2} \mathrm{O}$ with terbium-(III) nitrate pentahydrate, in deionized water, under vigorous stirring at room temperature. Subsequently, to this solution was added dropwise a solution of ammonium phosphate dibasic obtained in the same conditions. The ratio $\mathrm{Ca} / \mathrm{P}$ and $(\mathrm{Ca}+\mathrm{Tb}) / \mathrm{P}$ was maintained at 1.67 . The atomic ratio $\mathrm{Tb} /(\mathrm{Tb}+\mathrm{Ca})$ was varied between 0 and $10 \%$. The reaction was kept for $2 \mathrm{~h}$ under continuous stirring. Meanwhile, the resulting suspension was adjusted, and $\mathrm{pH}=10.5$ was maintained by adding $\mathrm{NH}_{4} \mathrm{OH}$ $(25 \%)$ solution. Undoped HAp was synthesized using a similar procedure, without the addition of terbium precursor. The resulting suspensions were kept for $24 \mathrm{~h}$. After matura- 
tion, the precipitates were filtered off, washed with deionized water at $\mathrm{pH}$ value close to 7.0 and finally dried in an air oven at $80^{\circ} \mathrm{C}$ for $12 \mathrm{~h}$.

\subsection{Characterization}

The structure of the obtained powders was investigated with a Nicolet iS50R spectrometer, in ATR mode at $4 \mathrm{~cm}^{-1}$ resolution, at room temperature. Each spectrum was measured in the range of $4000-400 \mathrm{~cm}^{-1}$. XRD spectra were recorded using a PANalytical Empyrean diffractometer at room temperature, with a Cu X-ray tube $(\lambda \mathrm{Cu} \mathrm{K} \alpha 1=1.541874 \AA$ ) $)$ operating with in-line focusing, with programmable divergent slit on the incident side and a programmable anti-scatter slit mounted on the PIXcel3D detector on the diffracted side. The diffraction patterns were collected in a Bragg-Brentano geometry, with a scanning step of $0.02^{\circ}$ and a $255 \mathrm{~s}$ measuring time per step. The XRD patterns were recorded in the $2 \theta$ scan ranging from $20^{\circ}$ to $80^{\circ}$. The lattice parameters mean crystallites sizes and strains were calculated using the High Score Plus 3.0e software and refined by the Rietveld method. A Quanta Inspect F50 FEG (field emission gun) scanning electron microscope with $1.2 \mathrm{~nm}$ resolution was used for SEM examinations. The microscope was equipped with an energy-dispersive X-ray (EDX) analyzer (resolution of $133 \mathrm{eV}$ at $\mathrm{MnK}_{\alpha}$, FEI Company) on sample covered with a thin gold layer. The bright field TEM micrographs were obtained using a Tecnai G2 F30 S-Twin high-resolution transmission electron microscope from Thermo Fisher (former FEI) (Waltham, MA, USA), which operated at an acceleration voltage of $300 \mathrm{kV}$. An Able Jasco V-560 spectrophotometer, with a scan speed of $200 \mathrm{~nm} / \mathrm{s}$, between 200 and $850 \mathrm{~nm}$, was used for obtaining the UV-Vis diffused reflectance spectra. The PL spectra were measured by using a Perkin Elmer LS 55 fluorescence spectrophotometer, with a scan speed of $200 \mathrm{~nm} / \mathrm{s}$ between 350 and $800 \mathrm{~nm}$, and with excitation and emission slit widths of $7 \mathrm{~nm}$. The used excitation wavelength was $320 \mathrm{~nm}$. The samples were finely ground by using an agate mortar and pestle. The fine powder was placed afterwards in the solid sample holder of the solid sample accessory of the device. The content of terbium in the mineral phase of the substituted hydroxyapatite was analyzed using an inductively coupled plasma mass spectrometry (ICP-MS). Prior to ICP-MS analysis (Agilent 8800, Agilent Technologies, Santa Clara, CA, USA), approximately $10 \mathrm{mg}$ of sample was dissolved in $100 \mu \mathrm{L}$ HNO3 and diluted in $10 \mathrm{~mL}$ volumetric flasks with ultrapure water. Solutions of $1 \mathrm{mg} / \mathrm{mL} \mathrm{Ca}_{10-\mathrm{x}} \mathrm{Tb}_{\mathrm{x}}\left(\mathrm{PO}_{4}\right)_{6}(\mathrm{OH})_{2}(\mathrm{x}=0,0.05,0.1,0.25,0.5,1)$ were further diluted by 1000 and 10,000 times, respectively. Calibration curves, ranging from $1 \mathrm{ppb}$ to $50 \mathrm{ppb}$, were prepared using multielement standard solution (multi-element calibration standard-2A, Agilent Technologies). Linear calibrations, with a correlation coefficient greater than 0.99 , were obtained for all elements.

\subsection{Cellular Viability Assays}

\subsubsection{MTT Assay}

The biocompatibility of synthesized terbium-doped hydroxyapatite samples was estimated using MTT [3-(4,5-dimethylthiazolyl)-2,5-diphenyltetrazolium bromide] assay (Vybrant ${ }^{\circledR}$ MTT Cell Proliferation Assay Kit, Thermo Fischer Scientific, Waltham, MA, USA). The human mesenchymal amniotic fluid stem cells (AFSC) were grown in DMEM medium (Sigma-Aldrich, Saint Luis, MO, USA) supplemented with 10\% fetal bovine serum, $1 \%$ antibiotics (penicillin and streptomycin) (Sigma-Aldrich, Saint Luis, MO, USA), changed twice a week. The growth of AFSC cells took place in 96-well plates, with a seeding density of 3000 cells/well in the presence of $\mathrm{Ca}_{10-\mathrm{x}} \mathrm{Tb}_{\mathrm{x}}\left(\mathrm{PO}_{4}\right)_{6}(\mathrm{OH})_{2}$ powders, for $72 \mathrm{~h}$. Subsequently, $15 \mathrm{~mL}(12 \mathrm{mM})$ of MTT was added to the cells, followed by incubation at 37 ${ }^{\circ} \mathrm{C}$ for $4 \mathrm{~h}$. A solution of $1 \mathrm{mg}$ Sodium Dodecyl Sulphate in $10 \mathrm{~mL} \mathrm{HCl}(0.01 \mathrm{M})$ was added and pipetted vigorously in order to solubilize the formed formazan crystals. A TECAN Infinite M200 spectrophotometer (Männedorf, Switzerland) at $570 \mathrm{~nm}$ was used to evaluate the optical density (OD) of solubilized formazan, after $1 \mathrm{~h}$. 


\subsubsection{GSH-Glo Glutathione Assay}

The oxidative stress assessment was performed using the GSH-Glo Glutathione Assay kit (Promega, WI, USA). AFSC was seeded at a density of 3000 cells in $300 \mu \mathrm{L}$ of Dulbecco's Modified Eagle's medium (DMEM) supplemented with 10\% fetal bovine serum and 1\% antibiotics (penicillin, streptomycin/neomycin) in 96-well plates. After $24 \mathrm{~h}$ of seeding, cells were treated with $\mathrm{Ca}_{10-\mathrm{x}} \mathrm{Tb}_{\mathrm{x}}\left(\mathrm{PO}_{4}\right)_{6}(\mathrm{OH})_{2}$ and then incubated for $72 \mathrm{~h}$. To this solution was added $100 \mu \mathrm{L} 1 \mathrm{X}$ GSH-Glo Reagent, followed by incubation at $37^{\circ} \mathrm{C}$ for $30 \mathrm{~min}$. Subsequently, $100 \mu \mathrm{L}$ Luciferin Detection Reagent was added and incubated at $37^{\circ} \mathrm{C}$ for an additional time of $15 \mathrm{~min}$. Afterwards, the medium from the wells was well homogenized and then the plate was read on the luminometer (Microplate Luminometer Centro LB 960, Berthold, Germany) [32-34].

\subsubsection{Fluorescence Microscopy}

A RED CMTPX fluorophore (Thermo Fischer Scientific, Waltham,, MA, USA) was used to evaluate the biocompatibility of the obtained $\mathrm{Ca}_{10-\mathrm{x}} \mathrm{Tb}_{\mathrm{x}}\left(\mathrm{PO}_{4}\right)_{6}(\mathrm{OH})_{2}(\mathrm{x}=0,0.05$, $0.1,0.25,0.5,1$ ) powders. The CMTPX (cell tracker for long-term tracing of living cells tracker) was added to the cell culture, previously treated with the synthesized nanoparticles. The viability and morphology of the AFSC was evaluated after 5 days. To allow the dye penetration into the cells, the CMTPX fluorophore, at a concentration of $5 \mu \mathrm{M}$ and incubated for $30 \mathrm{~min}$, was added in the culture medium. Finally, the AFSC were washed with PBS and visualized by fluorescent microscopy using an Olympus CKX 41 digital camera driven by CellSense Entry software (Olympus, Tokyo, Japan) [35].

\section{Results and Discussions}

\subsection{ICP-MS Analysis}

The concentration of terbium ions from doped HAp was analyzed by ICP-MS technique. Table 1 shows the measured concentrations, the correlation coefficient, and the limit of detection.

Table 1. Terbium ion contents for substituted HAp.

\begin{tabular}{|c|c|c|c|c|}
\hline Sample & Element & $\begin{array}{l}\mu \mathrm{g} \text { Element/mg } \\
\text { Sample }\end{array}$ & $\begin{array}{l}\text { Limit of Detection (LoD) } \\
{[\text { ug/L] }}\end{array}$ & Correlation Coefficient $\left(\mathrm{r}^{2}\right)$ \\
\hline $\mathrm{Ca}_{9.95} \mathrm{~Tb}_{0.05}\left(\mathrm{PO}_{4}\right)_{6}(\mathrm{OH})_{2}$ & \multirow{5}{*}{${ }^{159} \mathrm{~Tb}$} & 7.89 & \multirow{5}{*}{0.0002} & \multirow{5}{*}{0.997} \\
\hline $\mathrm{Ca}_{9.9} \mathrm{~Tb}_{0.1}\left(\mathrm{PO}_{4}\right)_{6}(\mathrm{OH})_{2}$ & & 25.11 & & \\
\hline $\mathrm{Ca}_{9.75} \mathrm{~Tb}_{0.25}\left(\mathrm{PO}_{4}\right)_{6}(\mathrm{OH})_{2}$ & & 41.27 & & \\
\hline $\mathrm{Ca}_{9.5} \mathrm{~Tb}_{0.5}\left(\mathrm{PO}_{4}\right)_{6}(\mathrm{OH})_{2}$ & & 70.66 & & \\
\hline $\mathrm{Ca}_{9} \mathrm{~Tb}_{1}\left(\mathrm{PO}_{4}\right)_{6}(\mathrm{OH})_{2}$ & & 110.37 & & \\
\hline
\end{tabular}

The data from Table 1 confirm the presence of terbium ions in doped hydroxyapatite powders. It was found that the content of dopant ion increases from 0 to 1 of ions doped HAp.

\subsection{FTIR Analysis}

Figure 1 shows the FTIR spectra of $\mathrm{Ca}_{10-\mathrm{x}} \mathrm{Tb}_{\mathrm{x}}\left(\mathrm{PO}_{4}\right)_{6}(\mathrm{OH})_{2}$ samples. The absorption bands characteristic of HAp and reported in literature [36] appear in the HAp spectrum. The FTIR spectrum of pure HAp (black line in Figure 1) shows a broad band in the region $3000-3400 \mathrm{~cm}^{-1}$ which corresponds to the -OH groups. The bands around 1090, 1023 and $960 \mathrm{~cm}^{-1}$ are due to the stretching mode of P-O [37]. The bands around $602 \mathrm{~cm}^{-1}, 562 \mathrm{~cm}^{-1}$ and $474 \mathrm{~cm}^{-1}$ are attributed to the bending mode of O-P-O [38]. The band at around $873 \mathrm{~cm}^{-1}$, which appears in all studied compound spectra, is due to the $\left[\mathrm{HPO}_{4}\right]^{2-}$ ions $[39,40]$. 


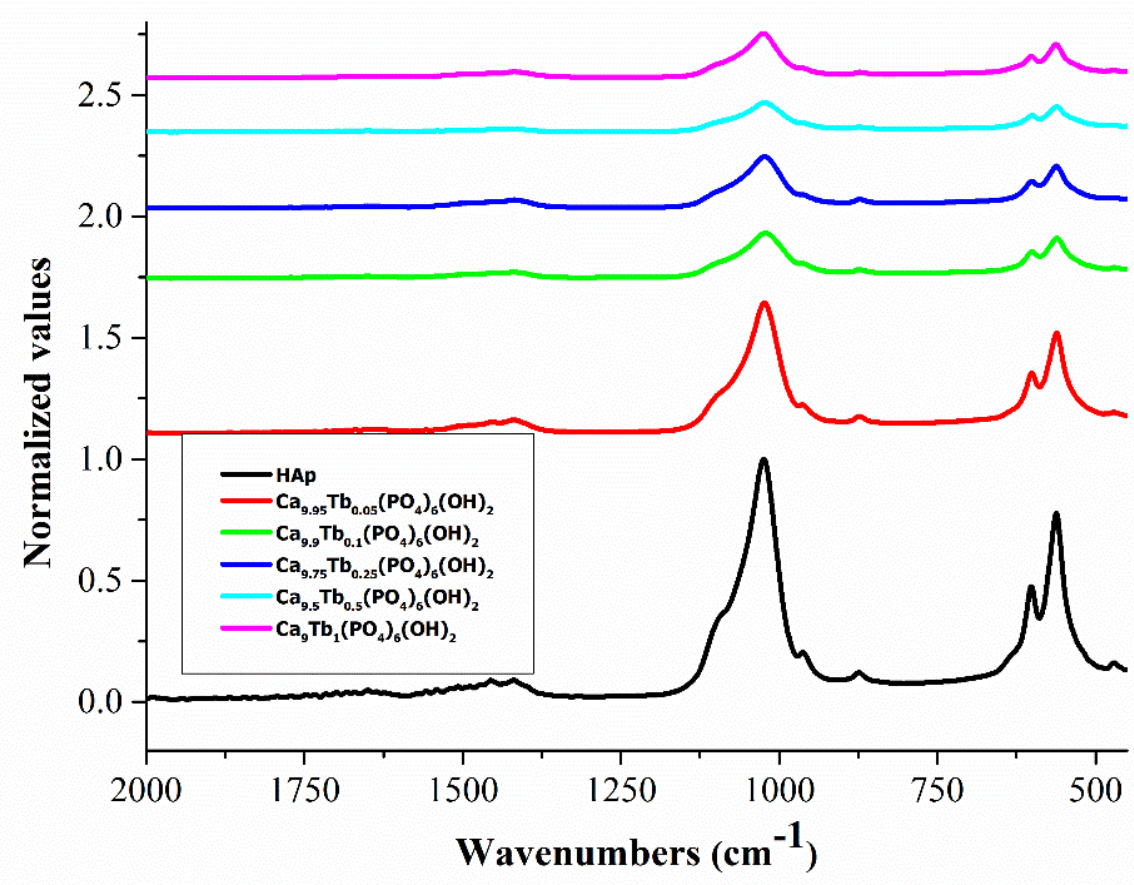

Figure 1. Normalized FTIR spectra of hydroxyapatite (HAp) and $\mathrm{Ca}_{10-\mathrm{x}} \mathrm{Tb}_{\mathrm{x}}\left(\mathrm{PO}_{4}\right)_{6}(\mathrm{OH})_{2}$.

Comparing the FTIR spectra, it can be seen that the spectra of $\mathrm{Ca}_{10-\mathrm{x}} \mathrm{Tb}_{\mathrm{x}}\left(\mathrm{PO}_{4}\right)_{6}(\mathrm{OH})_{2}$ powders with various rare earth concentrations are similar to the FTIR spectrum of pure HAp. In FTIR spectra of $\mathrm{Ca}_{10-\mathrm{x}} \mathrm{Tb}_{\mathrm{x}}\left(\mathrm{PO}_{4}\right)_{6}(\mathrm{OH})_{2}$ samples, the bands around 873 and $1426 \mathrm{~cm}^{-1}$ are assigned to $\mathrm{CO}_{3}{ }^{2-}$. This can be attributed to the $\mathrm{CO}_{3}{ }^{2-}$ groups replacing the $\mathrm{PO}_{4}{ }^{3-}$ groups, signifying an interaction between HAp and carbon dioxide from air [41]. The intensity of $\mathrm{PO}_{4}{ }^{3-}$ bands decreases with increasing terbium concentrations until the molar fraction of terbium is $0.1 \%$. Above this concentration, the banding bands of O-P-O increase. An explanation for this is that by replacing calcium ions with terbium ions, a change of bonding forces between the ions is induced, resulting in weakness of the banding bands of O-P-O [42]. The mechanism of substitution of Ca ions with rare earth ions has not been fully elucidated, on the basis of these studies. The increasing concentration of doped terbium ions caused a decrease in the intensity of the bands, associated with a decrease of HAp crystallinity.

\subsection{XRD Analysis}

The XRD patterns of the studied terbium-doped hydroxyapatite and undoped HAp reveal the formation of a pure hexagonal HAp phase (according to ICDD PDF4+ card no 00-068-0738, Figure 2 [43], in agreement with the literature [44-46]. The XRD patterns of the studied samples indicate only the pure hexagonal HAp phase of the space group $\mathrm{P} 6_{3} / \mathrm{m}$, along with all of the diffraction peaks in the HAp standard JCPDS database (PDF4+ card no 00-068-0738), such as: (002), (121), (112), (030), (022), (130), (222), (123) and (004).

The crystallinity degree and crystallite size of the studied samples are shown in Table 2, and an illustrative variation of those parameters is presented in Figure 2. In all of the studied samples, the peak intensities decrease with increasing terbium ion doping concentration level, signifying an interference of terbium ions with the crystal structure of HAp.

The average crystallite size of the undoped HAp was $6.07 \mathrm{~nm}$. For terbium-doped HAp samples, a decrease in crystallite size was observed with increasing ion dopant content. The lattice parameters of the terbium ion-doped HAp powders slowly decreased with increasing content of the terbium cations (Table 2). The introduction of $\mathrm{Tb}^{3+}$ in HAp lattice induces a decrease of crystallite size from 5.72 to $4.83 \mathrm{~nm}$ and an increase of microstain from $1.61 \%$ to $191 \%$. Then, for a substitution degree of more than $10 \%$, an increase of crystallite size up to $6.43 \mathrm{~nm}$ was observed. 


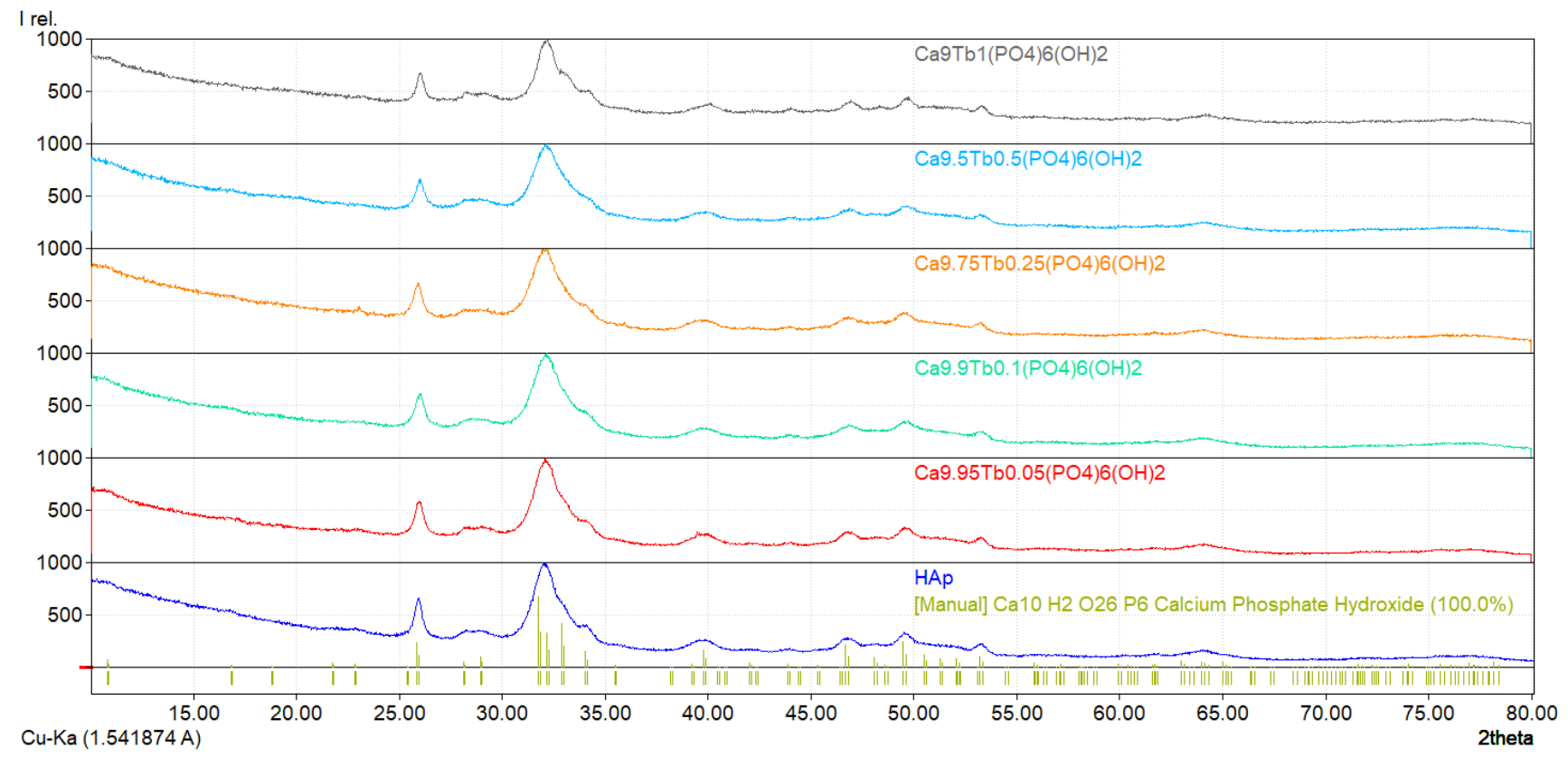

Figure 2. X-ray diffraction patterns of hydroxyapatite $(\mathrm{HAp})$ and $\mathrm{Ca}_{10-\mathrm{x}} \mathrm{Tb}_{\mathrm{x}}\left(\mathrm{PO}_{4}\right)_{6}(\mathrm{OH})_{2}$ powders.

Table 2. Calculated crystallite size (D) values and degree of crystallinity $\left(\chi_{c}\right)$ of pure HAp and terbium-doped hydroxyapatite with various concentrations.

\begin{tabular}{cccc}
\hline \multicolumn{1}{c}{ Samples } & $\mathrm{D} / \mathbf{n m}$ & $\mathrm{S} / \%$ & $\chi_{\mathbf{c}} / \%$ \\
\hline HAp & $6.07 \pm 0.82$ & $1.52 \pm 0.53$ & 31.50 \\
\hline $\mathrm{Ca}_{10-\mathrm{x}} \mathrm{Tb}_{\mathbf{x}}\left(\mathrm{PO}_{4}\right)_{6}(\mathrm{OH})_{2}$ & \\
\hline $\mathrm{Ca}_{9.95} \mathrm{~Tb}_{0.05}\left(\mathrm{PO}_{4}\right)_{6}(\mathrm{OH})_{2}$ & $5.72 \pm 0.76$ & $1.61 \pm 0.54$ & 37.40 \\
\hline $\mathrm{Ca}_{9.9} \mathrm{~Tb}_{0.1}\left(\mathrm{PO}_{4}\right)_{6}(\mathrm{OH})_{2}$ & $4.87 \pm 0.71$ & $1.89 \pm 0.60$ & 37.00 \\
\hline $\mathrm{Ca}_{9.75} \mathrm{~Tb}_{0.25}\left(\mathrm{PO}_{4}\right)_{6}(\mathrm{OH})_{2}$ & $4.66 \pm 0.72$ & $1.97 \pm 0.60$ & 35.02 \\
\hline $\mathrm{Ca}_{9.5} \mathrm{~Tb}_{0.5}\left(\mathrm{PO}_{4}\right)_{6}(\mathrm{OH})_{2}$ & $4.83 \pm 0.57$ & $1.91 \pm 0.69$ & 32.87 \\
\hline $\mathrm{Ca}_{9} \mathrm{~Tb}_{1}\left(\mathrm{PO}_{4}\right)_{6}(\mathrm{OH})_{2}$ & $6.43 \pm 0.70$ & $1.44 \pm 0.56$ & 28.95 \\
\hline
\end{tabular}

The lattice parameters $a=b$ and $c$ obtained from XRD peaks for undoped HAp have values of $\mathrm{a}=\mathrm{b}=9.4227 \AA$ and $\mathrm{c}=6.8837 \AA$, which is in accord with literature data $[47,48]$. The small changes in the lattice parameters are due to the ionic radius of terbium and calcium ions: $\mathrm{Tb}^{3+}(0.923 \AA)$ and for $\mathrm{Ca}^{2+}$ is $1 \AA$. The small differences observed for the studied samples are caused by the small differences in ionic radius [48]. When one ionic radius is greater than the others, a slow lattice expansion is observed. For terbium ions at low concentration, differences are not observed, but a higher substitution degree results in substantial changes in the unit cell parameters.

From the data in Table 3 and Figures 3 and 4 show the values of the unit cell parameters $a, c, V$ and the agreement indices obtained from Rietveld analysis $\left(R_{e x p}, R_{p}, R_{w p}\right.$ and $\left.\chi^{2}\right)$, an indication of the quality of fit, for hydroxyapatite HAp and terbium-doped HAp with different concentrations. The evaluation of crystallinity degree indicates a decrease in crystallinity with increasing ion dopant contents for all studied samples. 
Table 3. Unit cell parameters $a, c, V$ and agreement indices for hydroxyapatite $\mathrm{HAp}_{\mathrm{andCa}} \mathrm{Ca}_{10} \mathrm{~Tb}_{\mathrm{x}}\left(\mathrm{PO}_{4}\right)_{6}(\mathrm{OH})_{2}(\mathrm{with} \mathrm{x}=$ $0.05,0.1,0.25,0.5$ and 1$)$.

\begin{tabular}{|c|c|c|c|c|c|c|c|}
\hline Sample & $a[\AA]$ & $c[\AA]$ & $V\left[\AA^{3}\right]$ & $\mathbf{R}_{\exp }$ & $\mathbf{R}_{\mathrm{p}}$ & $\mathbf{R}_{\mathrm{wp}}$ & $x^{2}$ \\
\hline HAp & $9.4227 \pm 0.0033$ & $6.8837 \pm 0.0025$ & 529.3087 & 3.1050 & 4.5059 & 5.7040 & 3.3747 \\
\hline & \multicolumn{7}{|c|}{$\mathrm{Ca}_{10-\mathrm{x}} \mathrm{Tb}_{\mathrm{x}}\left(\mathrm{PO}_{4}\right)_{6}(\mathrm{OH})_{2}$} \\
\hline $\mathrm{Ca}_{9.95} \mathrm{~Tb}_{0.05}\left(\mathrm{PO}_{4}\right)_{6}(\mathrm{OH})_{2}$ & $9.4208 \pm 0.0030$ & $6.8846 \pm 0.0023$ & 529.1685 & 3.6765 & 3.8036 & 5.0633 & 1.8967 \\
\hline $\mathrm{Ca}_{9.9} \mathrm{~Tb}_{0.1}\left(\mathrm{PO}_{4}\right)_{6}(\mathrm{OH})_{2}$ & $9.4395 \pm 0.0037$ & $6.8903 \pm 0.0029$ & 531.7138 & 3.6495 & 3.6622 & 4.7929 & 1.7247 \\
\hline $\mathrm{Ca}_{9.75} \mathrm{~Tb}_{0.25}\left(\mathrm{PO}_{4}\right)_{6}(\mathrm{OH})_{2}$ & $9.4135 \pm 0.0043$ & $6.8844 \pm 0.0035$ & 528.3299 & 3.4967 & 3.4024 & 4.5551 & 1.6969 \\
\hline $\mathrm{Ca}_{9.5} \mathrm{~Tb}_{0.5}\left(\mathrm{PO}_{4}\right)_{6}(\mathrm{OH})_{2}$ & $9.4283 \pm 0.0046$ & $6.8788 \pm 0.0036$ & 529.5652 & 3.3414 & 3.3127 & 4.2472 & 1.6157 \\
\hline $\mathrm{Ca}_{9} \mathrm{~Tb}_{1}\left(\mathrm{PO}_{4}\right)_{6}(\mathrm{OH})_{2}$ & $9.4066 \pm 0.0037$ & $6.8901 \pm 0.0028$ & 527.9956 & 3.1025 & 2.9919 & 3.9236 & 1.5994 \\
\hline
\end{tabular}

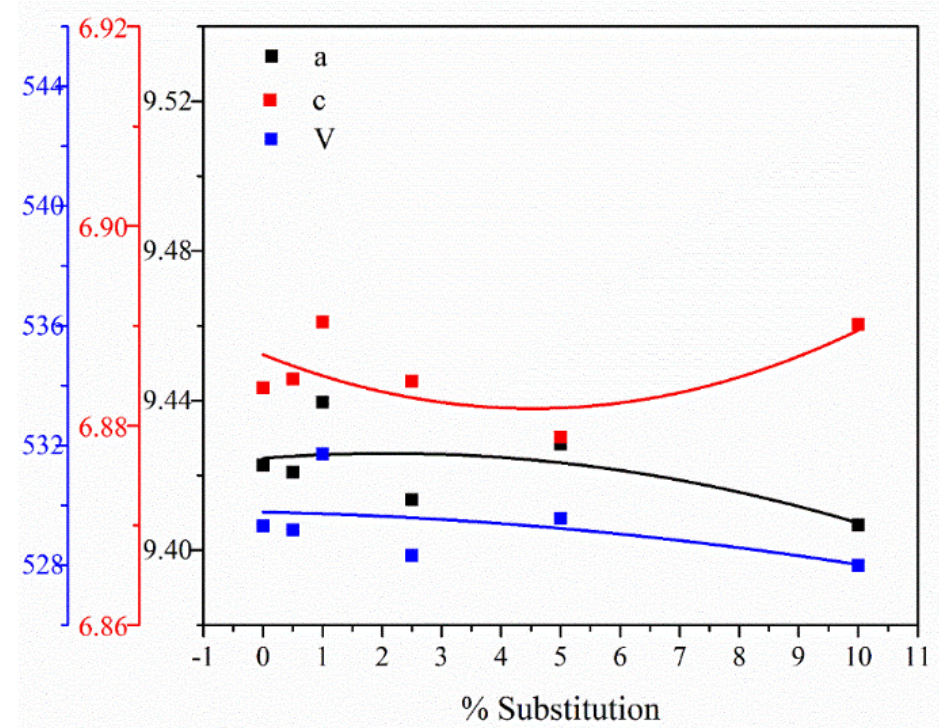

Figure 3. Unit cell parameters $(a, c, V)$ vs. substitution degree for $\mathrm{Ca}_{10-\mathrm{x}} \mathrm{Tb}_{\mathrm{x}}\left(\mathrm{PO}_{4}\right)_{6}(\mathrm{OH})_{2}$.

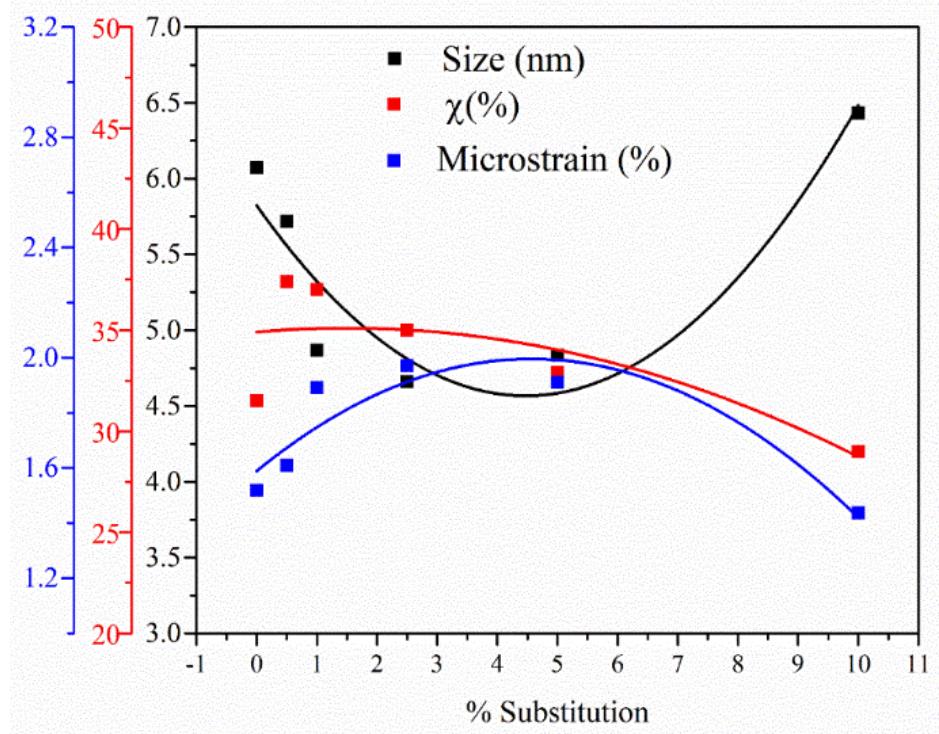

Figure 4. The estimated lattice microstrain, crystallite size and degree of crystallinity for $\mathrm{Ca}_{10-\mathrm{x}} \mathrm{Tb}_{\mathrm{x}}\left(\mathrm{PO}_{4}\right)_{6}(\mathrm{OH})_{2}$. 


\subsection{SEM Investigation}

The SEM morphologies of pure HAp and terbium-doped hydroxyapatite with various concentrations are shown in Figures 5 and 6. The SEM images recorded for HAp highlight a morphology with agglomerated nanoparticles, in the form of rods, but also intergranular spaces. The obtained particles have a size in the range of 5-9 $\mathrm{nm}$.

By doping with different concentrations of terbium ions, a small influence can be detected in the morphology of substituted HAp when compared to pure HAp.

Figure 6 shows SEM images of the hydroxyapatite doped with terbium of different concentrations. By doping hydroxyapatite with terbium ions, the morphology was modified. Thus, the nanoparticles become spherical, the agglomerates denser and their size is in the range of 3-7 nm. The SEM findings were supported by TEM analysis.

\subsection{TEM Investigation}

In Figure 7, TEM images of hydroxyapatite doped with terbium ion for $\mathrm{x}=0.05$ (Figure 7a), $x=0.25$ (Figure $7 \mathrm{~b}$ ) and $\mathrm{x}=1$ (Figure 7c) are shown. The bright field TEM images show a rod-like morphology of the particles specific to hydroxyapatite.

The TEM micrographs confirmed what was also shown in SEM images, in terms of the tendency to form agglomerates because of the nanometric dimensions of the particles and the decrease in particle size with increasing terbium content.

\subsection{UV-Vis and PL Spectra}

The UV-Vis spectra of terbium-doped hydroxyapatite powders from Figure 8a shows two shoulders at $242 \mathrm{~nm}$ and $259 \mathrm{~nm}$. The intensity of band observed at $242 \mathrm{~nm}$ increases with increasing terbium content. No other bands are observed in UV-Vis absorption spectra of terbium-doped hydroxyapatite powders.

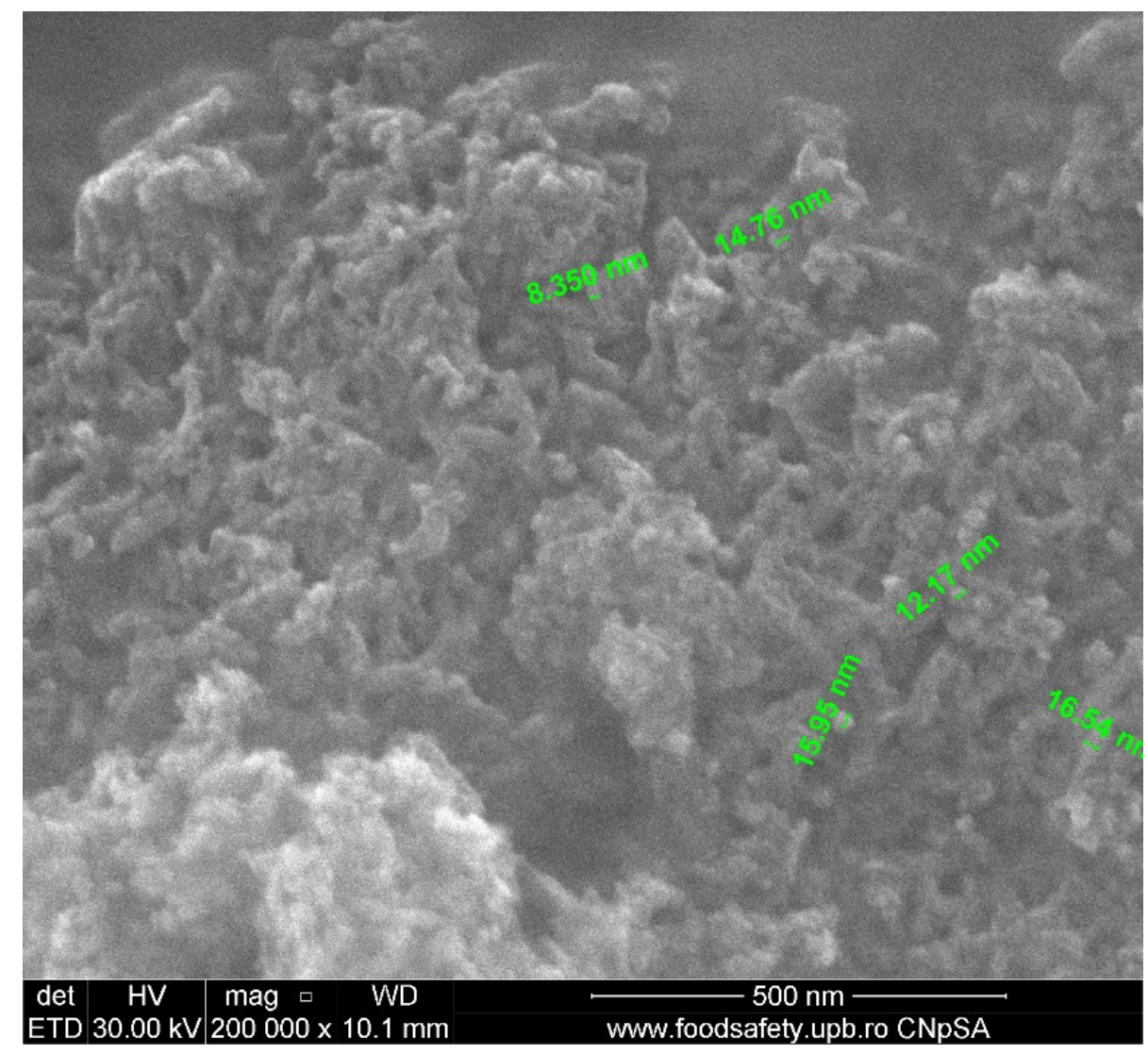

Figure 5. SEM image of pure HAp. 


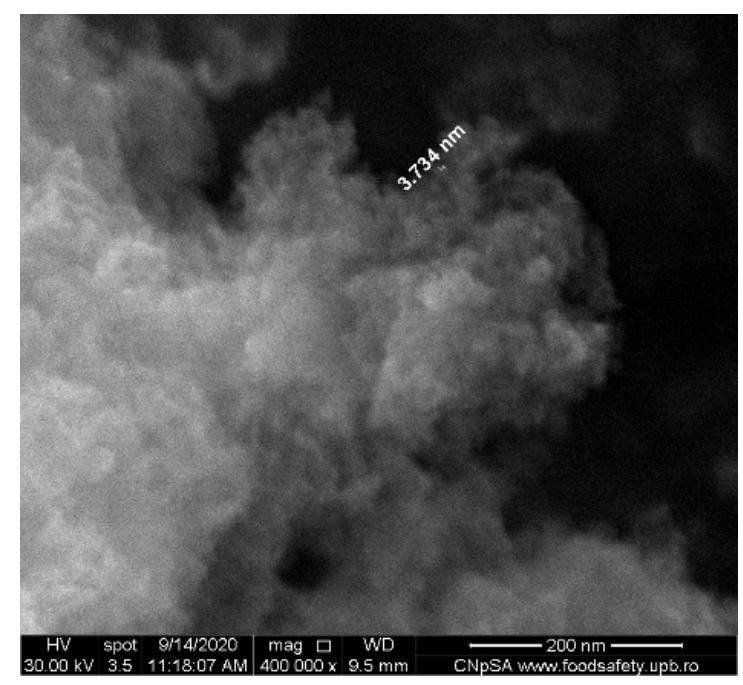

(a)

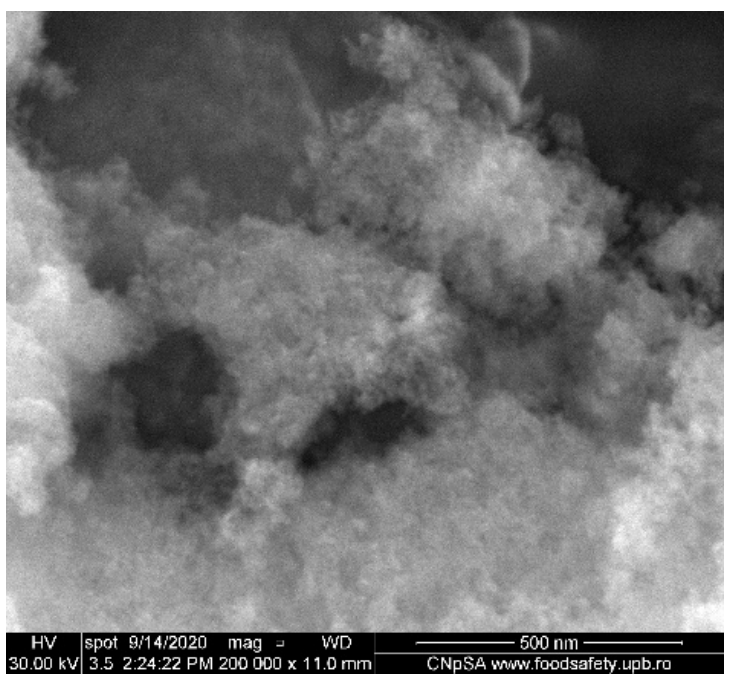

(c)

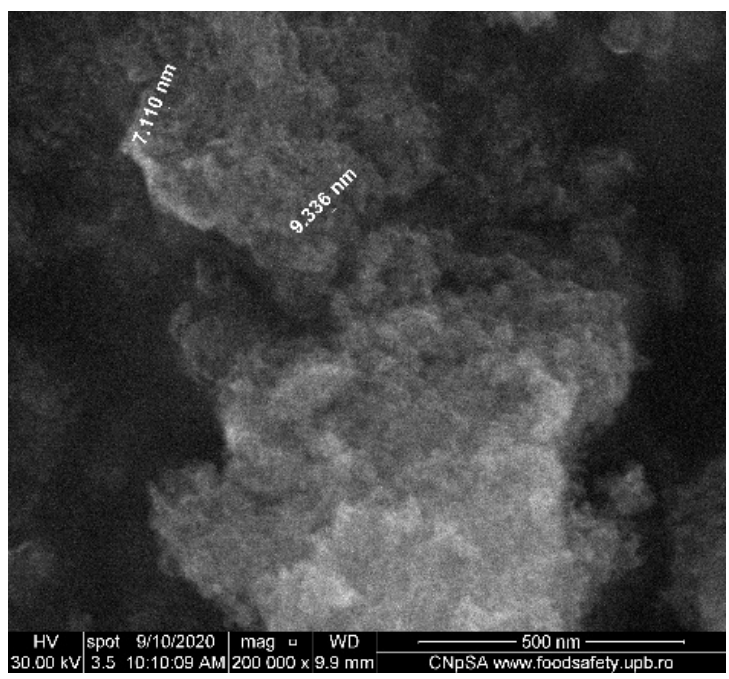

(b)

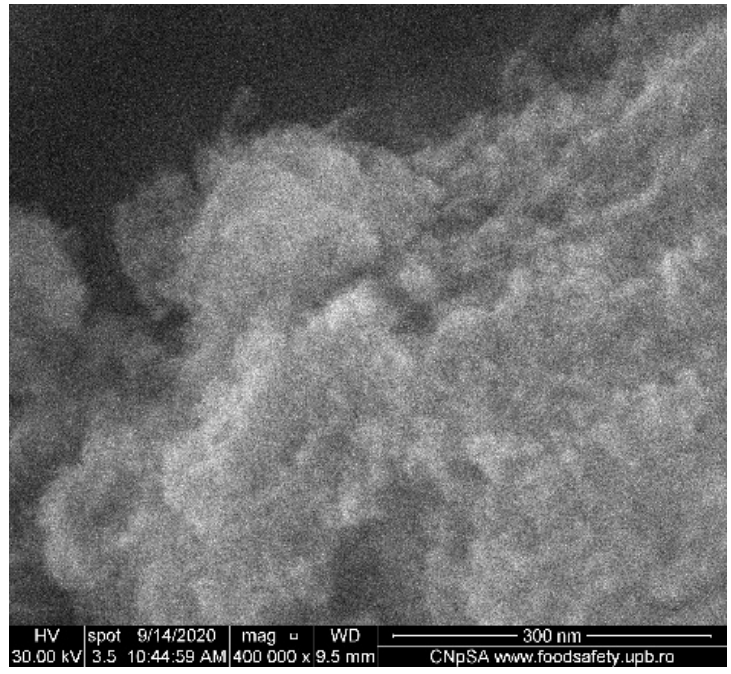

(d)

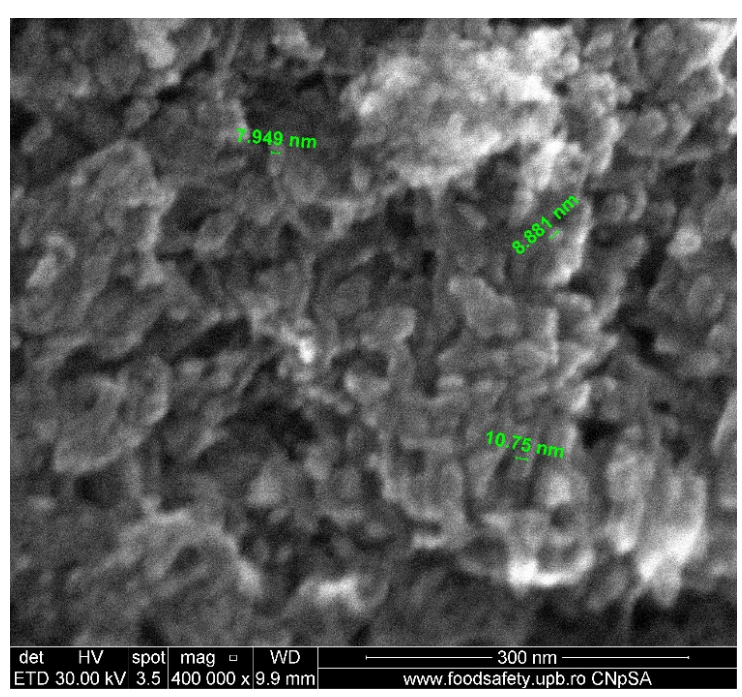

(e)

Figure 6. SEM images of $\mathrm{Ca}_{10-\mathrm{x}} \mathrm{Tb}_{\mathrm{x}}\left(\mathrm{PO}_{4}\right)_{6}(\mathrm{OH})_{2}(\mathbf{a}) \mathrm{x}=0.05 ;(\mathbf{b}) \mathrm{x}=0.1 ;(\mathbf{c}) \mathrm{x}=0.25 ;(\mathbf{d}) \mathrm{x}=0.5 ;(\mathbf{e}) \mathrm{x}=1$. 


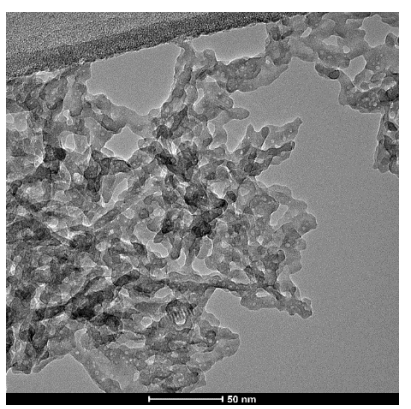

(a)

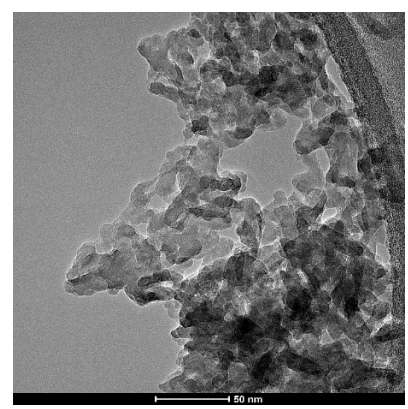

(b)

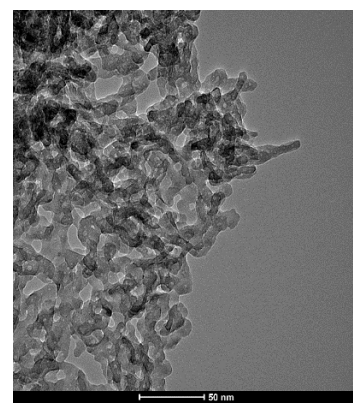

(c)

Figure 7. TEM images, for $x=0.05(\mathbf{a}), x=0.25(\mathbf{b}), x=1$ (c).

(a)

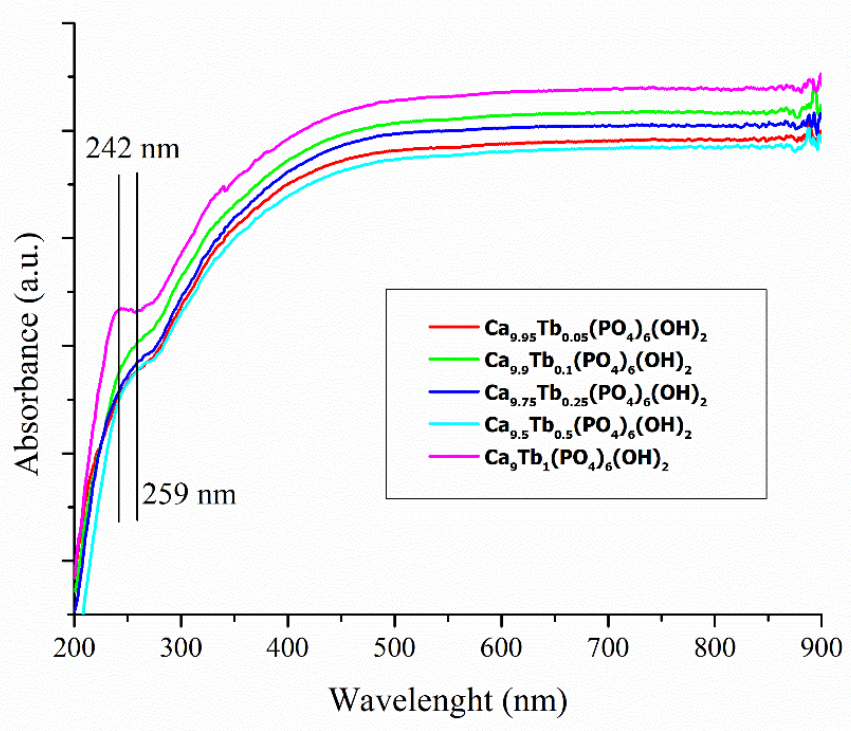

(b)

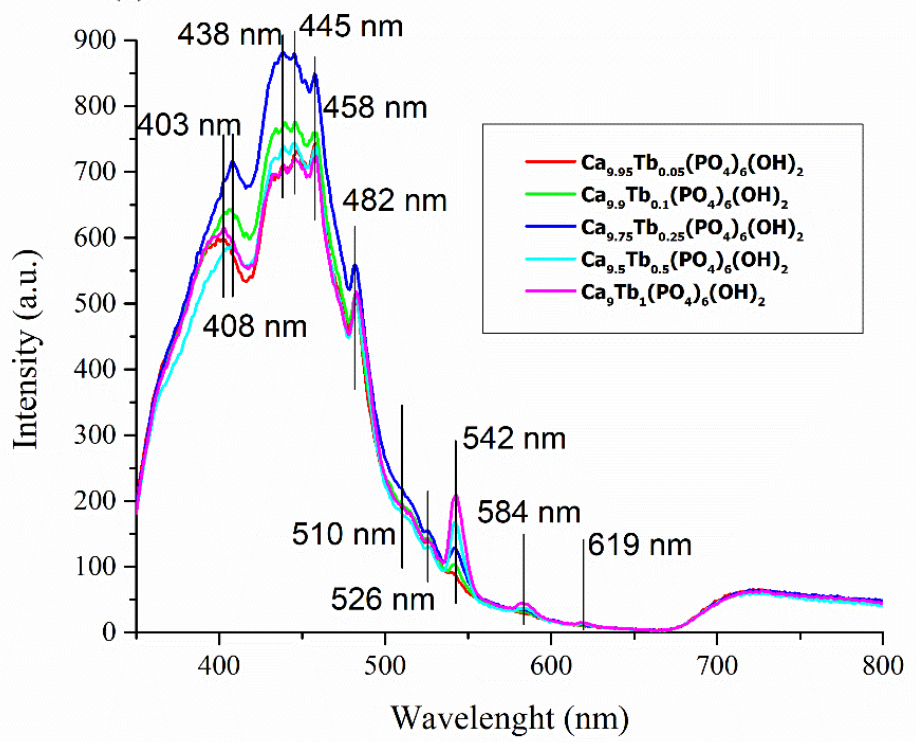

Figure 8. (a) UV-Vis absorption spectra of $\mathrm{Ca}_{10-\mathrm{x}} \mathrm{Tb}_{\mathrm{x}}\left(\mathrm{PO}_{4}\right)_{6}(\mathrm{OH})_{2} ;$ (b) PL spectra of $\mathrm{Ca}_{10-\mathrm{x}} \mathrm{Tb}_{\mathrm{x}}\left(\mathrm{PO}_{4}\right)_{6}(\mathrm{OH}) 2$. 
The PL emission spectra of $\mathrm{Ca}_{10-\mathrm{x}} \mathrm{Tb}_{\mathrm{x}}\left(\mathrm{PO}_{4}\right)_{6}(\mathrm{OH})_{2}$ at different concentrations from Figure $8 \mathrm{~b}$ present two distinct domains. The first domain, which covers a wavelength range from $350 \mathrm{~nm}$ to $530 \mathrm{~nm}$, contains emission bands due to the emission spectrum of HAp and oxygen vacancy, interstitial or oxygen antisites. The intensity of the PL emission spectra in this domain increases with terbium content up to $x=0.05$ and then decreases until $\mathrm{x}=1$. The most intense observed emission peaks are associated with: ${ }^{5} \mathrm{D}_{4} \rightarrow{ }^{7} \mathrm{~F}_{6}$ $(\sim 495 \mathrm{~nm}) ;{ }^{5} \mathrm{D}_{4} \rightarrow{ }^{7} \mathrm{~F}_{5}(542 \mathrm{~nm}) ;{ }^{5} \mathrm{D}_{4} \rightarrow{ }^{7} \mathrm{~F}_{4}(583 \mathrm{~nm}) ;$ and ${ }^{5} \mathrm{D}_{4} \rightarrow{ }^{7} \mathrm{~F}_{3}(619 \mathrm{~nm})$ [48]. The intensities of these maxima increase with increasing terbium content.

\subsection{Cell Viability and Cytotoxicity Assessment by MTT Assay, GSH Assay and Fluorescence Microscopy}

MTT assay from Figure 9 shows that the obtained terbium-doped hydroxyapatite nanomaterials present absorption values close to the control sample at $72 \mathrm{~h}$, proving their non-toxicological effect.

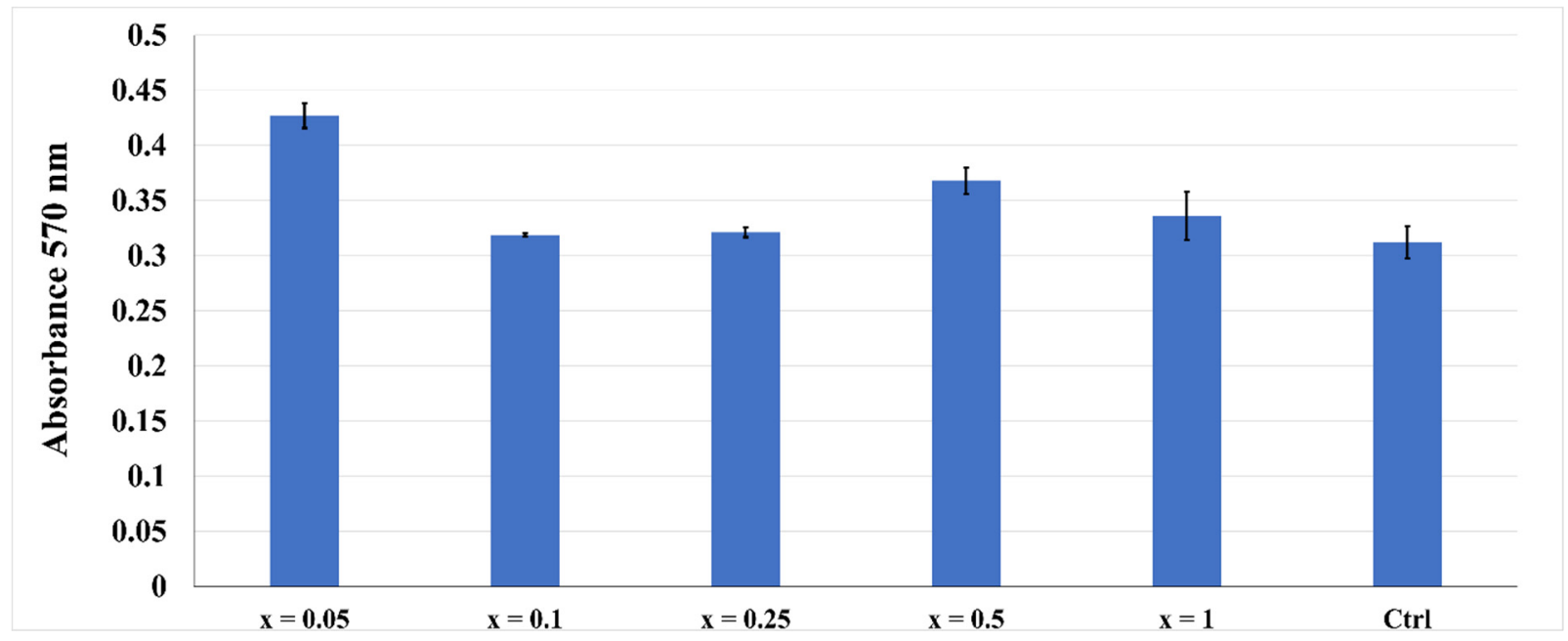

Figure 9. The viability of AFSC in the presence of the terbium-doped HAp by MTT assay.

Glutathione (Figure 10) has a response for all terbium-doped nanomaterials similar to the control cells, indicating that the obtained nanomaterials do not induce cellular stress.

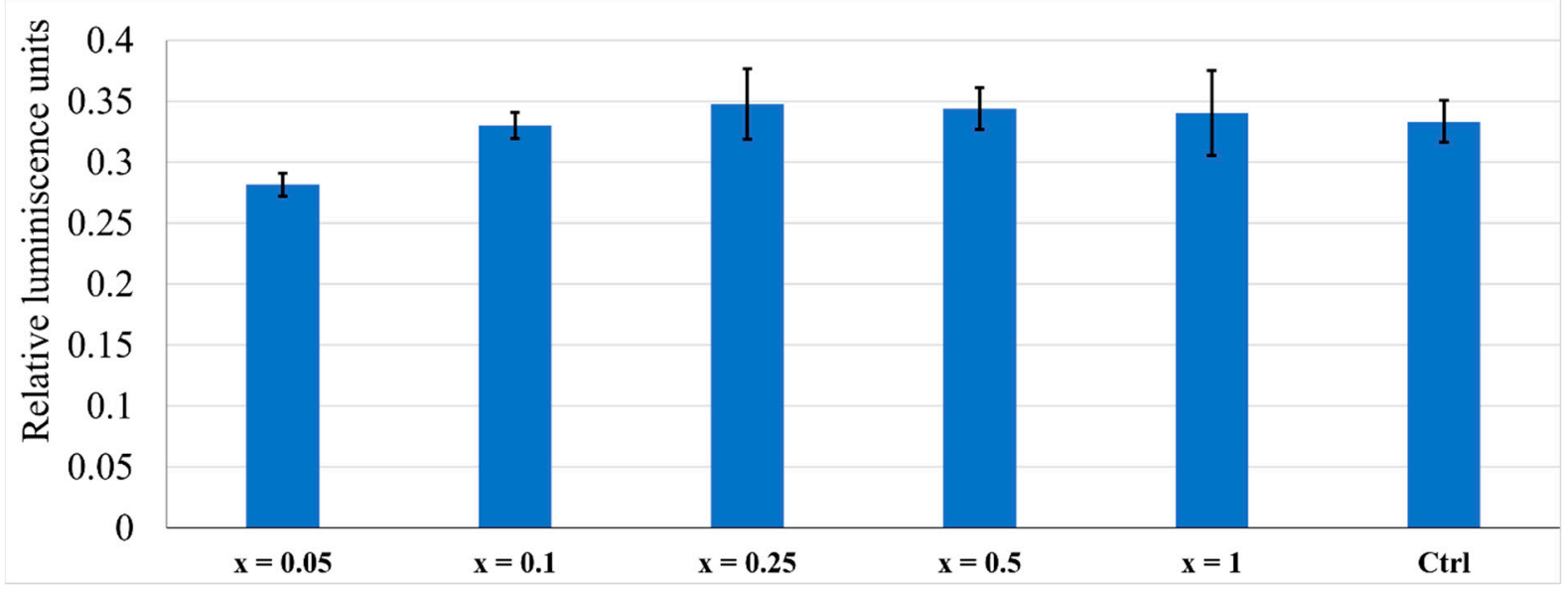

Figure 10. The AFSC of the terbium-doped HAp nanomaterials and control samples by GSH assay.

Fluorescence microscopy images in Figure 11 show the viability of AFSC cells; $\mathrm{Ca}_{10-\mathrm{x}} \mathrm{Tb}_{\mathrm{x}}\left(\mathrm{PO}_{4}\right)_{6}(\mathrm{OH})_{2}$ nanomaterial samples have no cytotoxic effect, confirming the 
biochemical results. No dead cells or cell fragments are detected; AFSCs have a normal morphology, with a distinctive appearance.

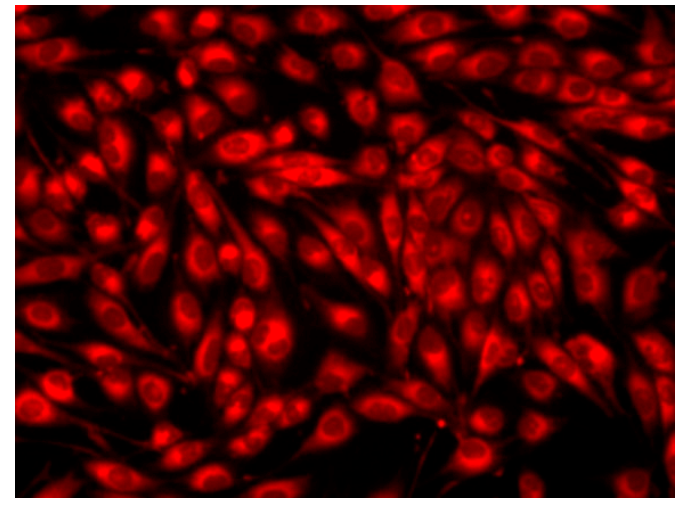

(a)

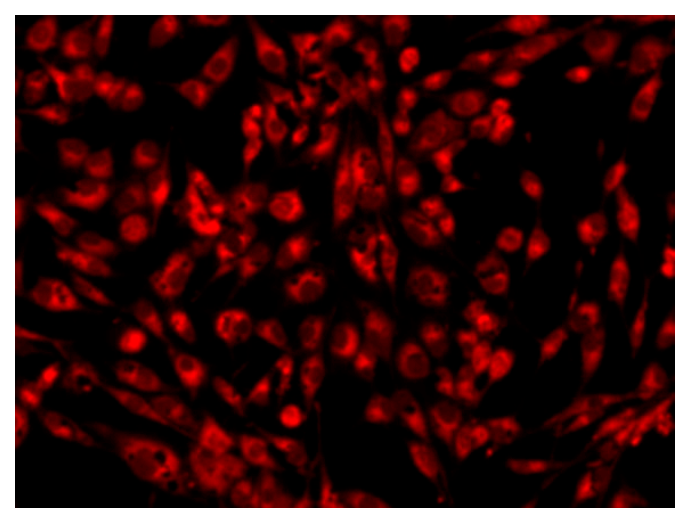

(c)

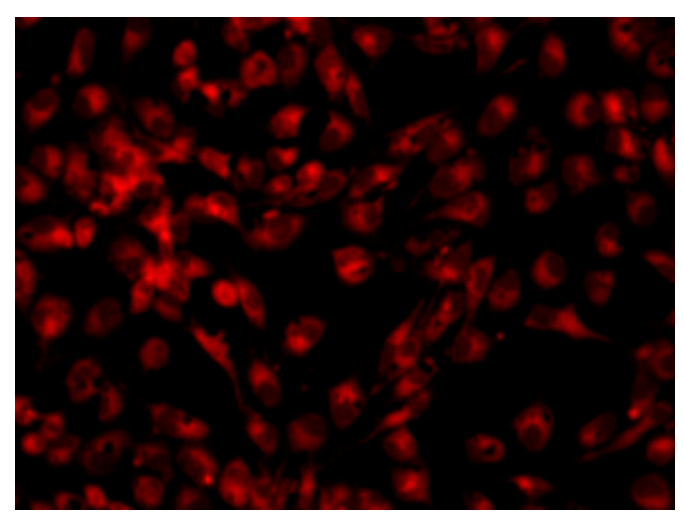

(e)

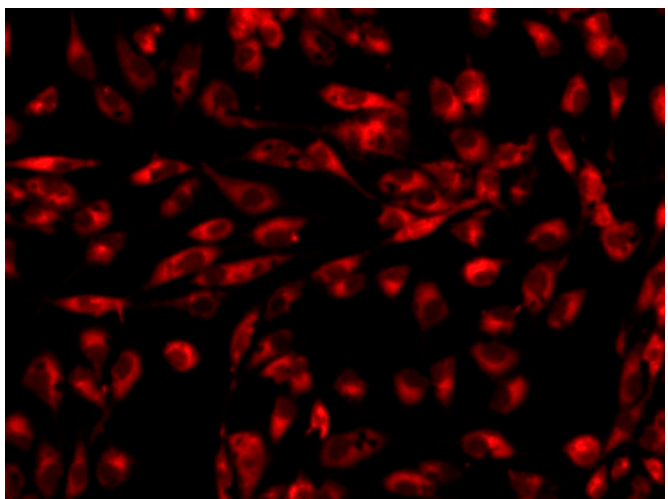

(b)

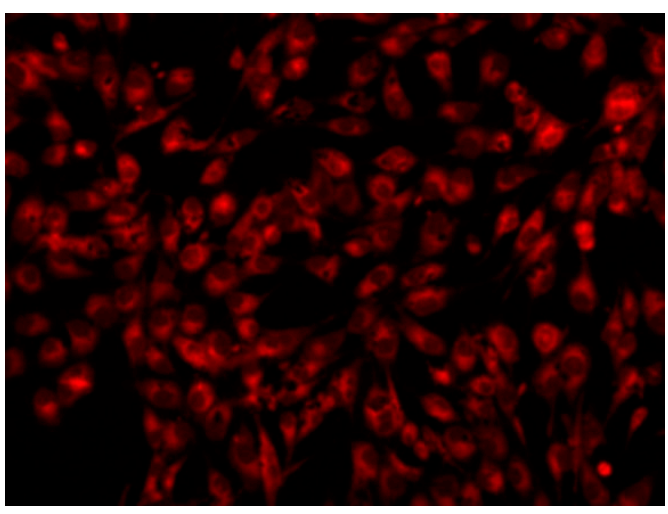

(d)

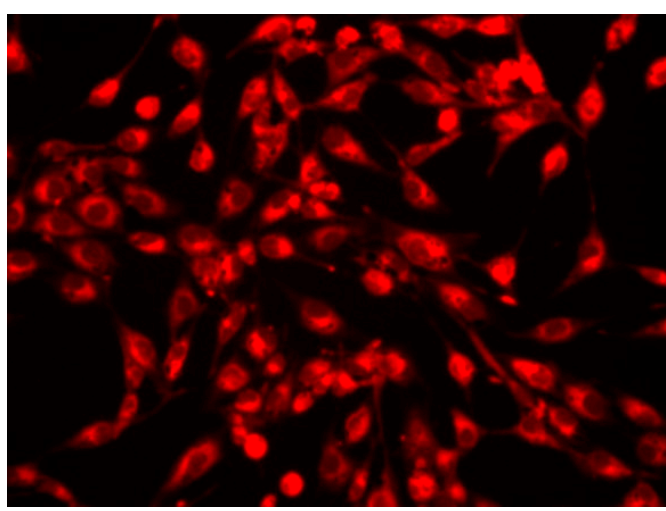

(f)

Figure 11. Fluorescence images of $\mathrm{Ca}_{10-\mathrm{x}} \mathrm{Tb}_{\mathrm{x}}\left(\mathrm{PO}_{4}\right)_{6}(\mathrm{OH})_{2}$ samples colored with CMTPX fluorophore: (a) control sample; (b) $\mathrm{x}=0.05 ;(\mathbf{c}) \mathrm{x}=0.1 ;(\mathrm{d}) \mathrm{x}=0.25 ;(\mathbf{e}) \mathrm{x}=0.5 ;(\mathbf{f}) \mathrm{x}=1$.

AFSC presents extensions that suggest an active phenotype. These are possible due to the activity of the cytoskeleton and mainly represent actin filaments and microtubules. Cellular metabolism is active, as shown by fluorescence microscopy images, with cells absorbing the fluorophore CMTPX dye in the cytoplasm, suggesting their viability after five days of incubation with amniotic fluid stem cells. 


\section{Conclusions}

In summary, the influence of terbium ions on the formation and structure of hydroxyapatite biomaterials synthesized by the coprecipitation method, was investigated. Different concentrations of terbium were considered, described by the formula $\mathrm{Ca}_{10-\mathrm{x}} \mathrm{Tb}_{\mathrm{x}}\left(\mathrm{PO}_{4}\right)_{6}(\mathrm{OH})_{2}$, where $\mathrm{x}=0.05 ; 0.1 ; 0.25 ; 0.5$ and 1 . The FTIR analysis and X-ray diffraction proved the successful replacement of the calcium ions from HAp lattice with terbium ions until a sample concentration of $x=0.5$ was achieved. Increasing concentration of terbium ions resulted in a decrease of HAp crystallinity. SEM and TEM analysis confirmed a spherical morphology with a tendency to form agglomerates, caused by their nanometric dimension. However, when doping of HAp is performed with different concentrations of terbium ions, it was shown to retain its physicochemical characteristics, while conferring new photoluminescence properties. The biocompatibility study of the obtained $\mathrm{Ca}_{10-\mathrm{x}} \mathrm{Tb}_{\mathrm{x}}\left(\mathrm{PO}_{4}\right)_{6}(\mathrm{OH})_{2}$ powders evaluated by fluorescence microscopy revealed a pronounced effect of cell viability and proliferation with the existence of a greater number of active cells. Therefore, the present study provides improved research consisting of obtaining terbium-doped hydroxyapatite nanomaterials with new photoluminescence properties for biomedical applications.

Author Contributions: The authors participated in the paper as follows: Conceptualization, A.V.P., B.S.V. and A.M.M.; methodology, E.A., B.S.V. and A.V.P.; validation, E.A., B.S.V. and A.M.M.; formal analysis, A.V.P., A.M.M., O.O. and F.I.; investigation, A.V.P., A.M.M., O.O. and F.I.; data curation, A.V.P. and A.M.M.; writing-original draft preparation, A.V.P. and A.M.M.; writing-review and editing, A.V.P., A.M.M. and B.S.V.; visualization, E.A.; supervision, E.A. and B.S.V.; project administration, E.A. All authors have read and agreed to the published version of the manuscript.

Funding: This research received no external funding.

Acknowledgments: The research activity of Andrei Viorel Paduraru and Adina Magdalena Musuc was supported by the project: UPB Proof of Concept. The support from the project "Innovative biomaterials for treatment and diagnosis, BIONANOINOV grant number PN-IIIP1-1.2-PCCD-I2017$0629^{\prime \prime}$ is highly appreciated by the rest of the team.

Conflicts of Interest: The authors declare no conflict of interest.

\section{References}

1. Akinfieva, O.; Nabiev, I.; Sukhanova, A. New directions in quantumdot-based cytometry detection of cancer se-rummarkers and tumor cells. Crit. Rev. Oncol./Hematol. 2013, 86, 1-14. [CrossRef]

2. Manoharan, M. Research on the frontiers of materials science: The impact of nanotechnology on new material devel-opment. Technol. Soc. 2008, 30, 401-404. [CrossRef]

3. Oryan, A.; Alidadi, S.; Moshiri, A.; Maffulli, N. Bone regenerative medicine: Classic options, novel strategies, and future directions. J. Orthop. Surg. Res. 2014, 9, 18. [CrossRef]

4. Dasgupta, S.; Banerjee, S.; Bandyopadhyay, A.; Bose, S. Zn- and Mg-Doped Hydroxyapatite Nanoparticles for Controlled Release of Protein. Langmuir 2010, 26, 4958-4964. [CrossRef] [PubMed]

5. Yilmaz, B.; Alshemary, A.Z.; Evis, Z. Co-doped hydroxyapatites as potential materials for biomedical applications. Microchem. J. 2019, 144, 443-453. [CrossRef]

6. Tsai, S.-W.; Huang, S.-S.; Yu, W.-X.; Hsu, Y.-W.; Hsu, F.-Y. Fabrication and Characteristics of Porous Hydroxyapatite-CaO Composite Nanofibers for Biomedical Applications. Nanomaterials 2018, 8, 570. [CrossRef] [PubMed]

7. Li, L.; Liu, Y.; Tao, J.; Zhang, M.; Pan, H.; Xu, X.; Tang, R. Surface Modification of Hydroxyapatite Nanocrystallite by a Small Amount of Terbium Provides a Biocompatible Fluorescent Probe. J. Phys. Chem. C 2008, 112, 12219-12224. [CrossRef]

8. Chane-Ching, J.-Y.; Lebugle, A.; Rousselot, I.; Pourpoint, A.; Pellé, F. Colloidal synthesis and characterization of monocrystalline apatite nanophosphors. J. Mater. Chem. 2007, 17, 2904-2913. [CrossRef]

9. Wang, F.; Tan, W.B.; Zhang, Y.; Fan, X.; Wang, M. Luminescent nanomaterials for biological labelling. Nanotechnology 2005, 17, R1-R13. [CrossRef]

10. Meiser, F.; Cortez, C.; Caruso, F. Biofunctionalization of Fluorescent Rare-Earth-Doped Lanthanum Phosphate Colloidal Nanoparticles. Angew. Chem. Int. Ed. 2004, 43, 5954-5957. [CrossRef] [PubMed]

11. Guo, D.; Wang, A.; Han, Y.; Xu, K. Characterization, physicochemical properties and biocompatibility of La-incorporated apatites. Acta Biomater. 2009, 5, 3512-3523. [CrossRef] [PubMed]

12. Šupová, M. Substituted hydroxyapatites for biomedical applications: A review. Ceram. Int. 2015, 41, 9203-9231. [CrossRef]

13. Zhou, W.Y.; Wang, M.; Cheung, W.L.; Guo, B.C.; Jia, D.M. Synthesis of carbonated hydroxyapatite nanospheres through nanoemulsion. J. Mater. Sci. Mater. Med. 2007, 19, 103-110. [CrossRef] [PubMed] 
14. Landi, E.; Tampieri, A.; Celotti, G.; Sprio, S. Densification behaviour and mechanisms of synthetic hydroxyapatites. J. Eur. Ceram. Soc. 2000, 20, 2377-2387. [CrossRef]

15. Li, H.; Zhao, X.; Cao, S.; Li, K.; Chen, M.; Xu, Z.; Lu, J.; Zhang, L. Na-doped hydroxyapatite coating on carbon/carbon com-posites: Preparation, in vitro bioactivity and biocompatibility. Appl. Surf. Sci. 2012, 263, 163-173. [CrossRef]

16. Kannan, S.; Ventura, J.; Ferreira, J. Synthesis and thermal stability of potassium substituted hydroxyapatites and hydroxyapatite/ $\beta$ tricalciumphosphate mixtures. Ceram. Int. 2007, 33, 1489-1494. [CrossRef]

17. Yan, Y.; Zhang, X.; Huang, Y.; Ding, Q.; Pang, X. Antibacterial and bioactivity of silver substituted hydroxyapatite/TiO 2 nanotube composite coatings on titanium. Appl. Surf. Sci. 2014, 314, 348-357. [CrossRef]

18. Zhang, W.; Cao, N.; Chai, Y.; Xu, X.; Wang, Y. Synthesis of nanosize single-crystal strontium hydroxyapatite via a simple sol-gel method. Ceram. Int. 2014, 40, 16061-16064. [CrossRef]

19. Thian, E.S.; Konishi, T.; Kawanobe, Y.; Lim, P.N.; Choong, C.; Ho, B.; Aizawa, M. Zincsubstituted hydroxyapatite: A bio-material with enhanced bioactivity and antibacterial properties. J. Mater. Sci. Mater. Med. 2013, 24, 437-445. [CrossRef]

20. Shanmugam, S.; Gopal, B. Copper substituted hydroxyapatite and fluorapatite: Synthesis, characterization and antimicrobial properties. Ceram. Int. 2014, 40, 15655-15662. [CrossRef]

21. Chandra, V.S.; Baskar, G.; Suganthi, R.V.; Elayaraja, K.; Joshy, M.I.A.; Beaula, W.S.; Mythili, R.; Venkatraman, G.; Kalkura, S.N. Blood Compatibility of Iron-Doped Nanosize Hydroxyapatite and Its Drug Release. ACS Appl. Mater. Interfaces 2012, 4, 1200-1210. [CrossRef]

22. Nie, Y.; Hu, C.; Kong, C. Enhanced fluoride adsorption using Al (III) modified calcium hydroxyapatite. J. Hazard. Mater. 2012, 233-234, 194-199. [CrossRef]

23. Tite, T.; Popa, A.-C.; Balescu, L.M.; Bogdan, I.M.; Pasuk, I.; Ferreira, J.M.F.; Stan, G.E. Cationic Substitutions in Hydroxyapatite: Current Status of the Derived Biofunctional Effects and Their In Vitro Interrogation Methods. Materials 2018, 11, 2081. [CrossRef]

24. Neacsu, I.A.; Stoica, A.E.; Vasile, B.S.; Andronescu, E. Luminescent Hydroxyapatite Doped with Rare Earth Elements for Biomedical Applications. Nanomaterials 2019, 9, 239. [CrossRef]

25. Lin, Y.; Yang, Z.; Cheng, J. Preparation, Characterization and Antibacterial Property of Cerium Substituted Hydroxyapatite Nanoparticles. J. Rare Earths 2007, 25, 452-456. [CrossRef]

26. Kar, A.; Patra, A. Impacts of core-shell structures on properties of lanthanide-based nanocrystals: Crystal phase, lattice strain, downconversion, upconversion and energy transfer. Nanoscale 2012, 4, 3608-3619. [CrossRef]

27. Deopa, N.; Rao, A. Spectroscopic studies of single near ultraviolet pumped Tb3+ doped Lithium Lead Alumino Borate glasses for green lasers and tricolour w-LEDs. J. Lumin. 2018, 194, 56-63. [CrossRef]

28. Bin Chen, B.; Liu, M.L.; Zhan, L.; Li, C.M.; Huang, C.Z. Terbium(III) Modified Fluorescent Carbon Dots for Highly Selective and Sensitive Ratiometry of Stringent. Anal. Chem. 2018, 90, 4003-4009. [CrossRef] [PubMed]

29. Materials, S.E.; Cells, S. Luminescent Layers for Enhanced Silicon Solar Cell Performance: Down-Conversion. Sol. Energy Mater. Sol. Cells 2016. [CrossRef]

30. Wei, Y.; He, Y.; Li, X.; Chen, H.; Deng, X. Cellular Uptake and Delivery-Dependent Effects of Tb3+-Doped Hydroxyapatite Nanorods. Molecules 2017, 22, 1043. [CrossRef]

31. Chen, M.H.; Yoshioka, T.; Ikoma, T.; Hanagata, N.; Lin, F.H.; Tanaka, J. Photolumi-nescence and doping mechanism of theranostic Eu3+/Fe3+ dual-doped hydroxyapatite nanoparticles. Sci. Technol. Adv. Mater. 2014, 15. [CrossRef]

32. Nicoara, A.I.; Ene, V.L.; Voicu, B.B.; Bucur, M.A.; Neacsu, I.A.; Vasile, B.S.; Iordache, F. Biocompatible Ag/Fe-Enhanced TiO2 Nanoparticles as an Effective Compound in Sunscreens. Nanomaterials 2020, 10, 570. [CrossRef] [PubMed]

33. Andronescu, E.; Predoi, D.; Neacsu, I.A.; Paduraru, A.V.; Musuc, A.M.; Trusca, R.; Oprea, O.; Vasile, E.; Vasile, O.R.; Nicoara, A.I.; et al. Photoluminescent Hydroxylapatite: Eu3+ Doping E_ect on Biological Behaviour. Nanomaterials 2019, 9, 1187. [CrossRef] [PubMed]

34. Paduraru, A.V.; Musuc, A.M.; Oprea, O.C.; Trusca, R.; Iordache, F.; Vasile, B.S.; Andronescu, E. Synthesis and Character-ization of Photoluminescent Ce(III) and Ce(IV) Substituted Hydroxyapatite Nanomaterials by Co-Precipitation Meth-od: Cytotoxicity and Biocompatibility Evaluation. Nanomaterials 2021, 11, 1911. [CrossRef] [PubMed]

35. Paduraru, A.; Ghitulica, C.; Trusca, R.; Surdu, V.A.; Neacsu, I.A.; Holban, A.; Bîrca, A.; Iordache, F.; Vasile, B.S. Antimi-crobial Wound Dressings as Potential Materials for Skin Tissue Regeneration. Materials 2019, 12, 1859. [CrossRef] [PubMed]

36. Dhand, V.; Rhee, K.Y.; Park, S.J. The facile and low temperature synthesis of nanophase hydroxyapatite crystals using wet chemistry. Mater. Sci. Eng. C 2014, 36, 152-159. [CrossRef]

37. Yuan, Q.; Qin, C.; Wu, J.; Xu, A.; Zhang, Z.; Liao, J.; Lin, S.; Ren, X.; Zhang, P. Synthesis and characterization of Cerium-doped hydroxyapatite/polylactic acid composite coatings on metal sub-strates. Mater. Chem. Phys. 2016, 182, 365-371. [CrossRef]

38. Feng, Z.; Liao, Y.; Ye, M. Synthesis and structure of cerium-substituted hydroxyapatite. J. Mater. Sci. Mater. Med. 2005, 16, 417-421. [CrossRef] [PubMed]

39. Li, H.; Sun, X.; Li, Y.; Li, B.; Liang, C.; Wang, H. Materials Science \& Engineering C Preparation and properties of carbon nanotube ( Fe )/ hydroxyapatite composite as magnetic targeted drug delivery carrier. Mater. Sci. Eng. C 2019, 97, $222-229$.

40. Mondal, S.; Dey, A.; Pal, U. Low temperature wet-chemical synthesis of spherical hydroxyapatite nanoparticles and their in situ cytotoxicity study. Adv. Nano Res. 2016, 4, 295-307. [CrossRef]

41. Murugan, R.; Ramakrishna, S. Production of ultra-fine bioresorbable carbonated hydroxyapatite. Acta Biomater. 2006, 2, 201-206. [CrossRef] 
42. Veselinovic, L.; Karanovic, L.; Stojanovic, Z.; Bracko, I.; Markovic, S.; Ignjatovic, N.; Uskokovic, D. Crystal structure of cobaltsubstituted calcium hydroxyapatite nanopowders prepared by hydrothermal processing. J. Appl. Cryst. $2010,43,320-327$. [CrossRef]

43. Lima, T.A.; Valerio, M.E. X-ray absorption fine structure spectroscopy and photoluminescence study of multifunctional europium (III)-doped hydroxyapatite in the presence of cationic surfactant medium. J. Lumin. 2018, 201, 70-76. [CrossRef]

44. Elliott, J.C. Structure and Chemistry of the Apatites and Other Calcium Orthophosphates; Elsevier: Amsterdam, The Netherlands, 1994; Volume 18, 404p.

45. Suzuki, T.; Hatsushika, T.; Miyake, M. Synthetic hydroxyapatites as inorganic cation exchangers. Part 2. J. Chem. Soc. Faraday Trans. 1 Phys. Chem. Condens. Phases 1982, 178, 3605-3611. [CrossRef]

46. Gaines, R.V.; Skinner, H.C.; Foord, E.E.; Mason, B.; Rosenzweig, A. Dana's New Mineralogy; John Wiley \& Sons Inc.: New York, NY, USA, 1997.

47. Klein, C.; Dutrow, B. Mineral Science; John Wiley \& Sons Inc.: New York, NY, USA, 2008.

48. Jiménez-Flores, Y.; Suárez-Quezada, M.; Rojas-Trigos, J.B.; Lartundo-Rojas, L.; Suárez, V.; Mantilla, A. Characterization of Tb-doped hydroxyapatite for bio-medical applications: Optical properties and energy band gap determination. J. Mater. Sci. 2017, 52, 9990-10000. [CrossRef] 